\title{
Original article \\ Effect of different exercise programs on the psychological and cognitive functions of people with Parkinson's disease
}

\author{
Lilian Teresa Bucken Gobbi \\ Claudia Teixeira-Arroyo \\ Ellen Lirani-Silva \\ Rodrigo Vitório \\ Fabio Augusto Barbieri \\ Marcelo Pinto Pereira \\ São Paulo State University, Brazil
}

\begin{abstract}
The purpose of this study was to analyze the effect of different exercise programs on the psychological and cognitive functions in patients with Parkinson's disease (PD). Forty-five patients with PD participated in the study. The participants were randomized in three intervention programs: Group-1 ( $\mathrm{n}=15$, cognitive-activities), Group-2 ( $\mathrm{n}=15$, multimodal exercise) and Group- 3 ( $\mathrm{n}=15$, exercises for posture and gait). The clinical, psychological and cognitive functions were assessed before and after 4 months of intervention. Univariate analysis did not reveal significant interactions between groups and time $(p>0.05)$. However, univariate analysis for time revealed differences in stress level and memory. Participants showed less physical stress $(p<0.01)$ and overall stress $(p<$ $0.04)$ and higher performance in episodic declarative memory $(\mathrm{p}<0.001)$ after exercise. These findings suggest that group work with motor or non-motor activities can improve cognitive and psychological functions of patients with PD.
\end{abstract}

Keywords: exercise, psychological functions, cognitive functions. Parkinson's disease

Resumo- -Efeito de diferentes programas de exercício sobre as funções psicológicas e cognitivas das pessoas com doença de Parkinson." O objetivo deste estudo foi analisar o efeito de diferentes programas de exercício físico nas funções psicológicas e cognitivas em pacientes com doença de Parkinson (DP). Participaram do estudo 45 pacientes com DP, distribuídos aleatoriamente em três programas de intervenção: Grupo-1 $(n=15$, atividades cognitivas), Grupo-2 ( $\mathrm{n}=15$ exercício multimodal) e Grupo-3 ( $\mathrm{n}=15$, exercícios para a postura e a marcha). As funções clínicas, psicológicas e cognitivas foram avaliadas antes e após 4 meses de intervenção. A análise univariada não revelou interação significativa entre grupo e momento $(p>0,05)$. No entanto, a análise univariada para momento revelou diferenças no nível de estresse e memória. Os participantes mostraram redução do estresse físico $(p<0,01)$ e estresse global $(p<0,04)$ e melhora na memória declarativa episódica $(p<0,001)$ após a intervenção. Estes achados sugerem que o trabalho em grupo, com atividades motoras ou não motoras, pode melhorar as funções cognitivas e as condições psicológicas de pacientes com DP.

Palavras-chaves: exercício, funções psicológicas, funções cognitivas, doença de Parkinson

Resumen-"Efecto de los diferentes programas de ejercicios en las funciones psicológicas y cognitivas de las personas con enfermedad de Parkinson." El objetivo del estudio fue analizar el efecto de diferentes programas de ejercicios en las funciones cognitivas y psicológicas en pacientes con enfermedad de Parkinson (EP). Cuarenta y cinco pacientes con EP que fueron divididos aleatoriamente en tres intervenciones: Grupo-1 ( $\mathrm{n}=15$, actividades cognitivas), Grupo-2 ( $\mathrm{n}=15$ ejercicio multimodal) y Grupo-3 ( $\mathrm{n}=15$, ejercicios para la postura y la marcha). Las funciones clínicas, psicológicas y cognitivas fueron evaluadas antes y después de 4-meses de intervención. Análisis univariante reveló interacción significativa entre el grupo y el tiempo $(p>0,05)$. Obstante, análisis univariada para tiempo reveló diferencias en el nivel de estrés y la memoria. Los participantes mostraron una reducción del estrés físico $(p<0,01)$ y el estrés en general $(p<0,04)$ y mejora de la memoria declarativa episódica $(p<0,001)$ después de la intervención. Estos hallazgos sugieren que el trabajo en grupo, actividades motoras y non-motoras, pueden mejorar las funciones cognitivas y psicológicas de los pacientes con EP.

Palabras claves: ejercicio, funciones psicológicas, funciones cognitivas, enfermedad de Parkinson 


\section{Introduction}

Parkinson's disease (PD) is the most common neurodegenerative disorder, and it involves a progressive loss of midbrain dopaminergic neurons as the major neurochemical finding. A recent population-based cohort study showed that Parkinson's disease (PD) has a prevalence of 3.3\% in older Brazilian adults (Barbosa, Caramelli, Maia, Cunningham, Guerra, \& Lima-Costa, 2006). Despite the fact that PD is characterized by movement disorders, such as tremor, rigidity and bradykinesia (Olanow, Stern, \& Sethi, 2009), neuropsychological studies have revealed deficits in a range of cognitive functions (Braak, Rub, \& Tredici, 2006; Hely, Morris, Reid, Adena, \& Halliday, 2008; Sawamoto, Piccini, Hotton, Pavese, Thielemans, \& Brooks, 2008). In the cognitive domains, memory decline is the most common deficit in patients with PD, followed by visuospatial orientation and executive function impairment (Aarsland, Bronnick, Williams-Gray, Weintraub, Marder, Kulisevsky et al., 2010).

Although the cognitive decline usually appears late, it can also be an early symptom and may even come to dominate the clinical features (Aarsland, Andersen, Larsen, Lolk, \& Kragh-Sorensen, 2003; Korczyn, 2001). After a 20year follow-up of patients newly diagnosed with PD, dementia is present in $83 \%$ of 20-year survivors (Hely, Morris, Reid, Adena, \& Halliday, 2008). The presence of cognitive dysfunction and dementia may affect the prognosis of PD (Parashos, Maraganore, O'Brien, \& Rocca, 2002), contribute to an increased tendency to fall (Wielinski, Erickson-Davis, Wichmann, Walde-Douglas, \& Parashos, 2005) and interfere in activities of daily living (Bronnick, Ehrt, Emre, De Deyn, Wesnes, Tekin et al., 2006; Devos, Vandenberghe, Nieuwboer, Tant, Baten, \& De Weerdt, 2007).

The symptoms of PD patients tend to worsen progressively (Karlsen, Tandberg, Arsland, \& Larsen, 2000) even though exercise interventions have shown some benefits to patients (Olanow, Stern, \& Sethi, 2009; Pereira, Ferreira, Caetano, Vitório, Lirani-Silva, Barbieri et al., 2012; Sage \& Almeida, 2009; Tanaka, Quadros Jr., Santos, Stella, Gobbi, \& Gobbi, 2009; Vitório, Teixeira-Arroyo, Lirani-Silva, Barbieri, Caetano, Gobbi et al., 2011). In order to have an active life style to minimize the progression of chronic diseases, the American College of Sports Medicine (Chodzko-Zajko, Proctor, Fiatarone-Singh, Minson, Nigg, Salem et al., 2009) recommends that elderly populations in general, including PD patients, get a minimum number of hours per week of physical exercise. A very recent clinical trial has shown that PD patients can change their behavior from sedentary to active with information and encouragement (van Nimwegen, Speelman, Overeem, van de Warrenburg, Smulders, Dontje et al, 2013). Positive results of enrollment in exercise programs were found for motor symptoms, muscular strength and sensorial orientation (Hirsch, Toole, Maitland, \& Rider, 2003) walking (Vitório et al., 2011), mobility (Pereira et al., 2012), coordination and on the UPDRS-motor score (Sage \& Almeida, 2010).
Despite cognitive dysfunction and dementia (non-motor symptoms) that have been detected in PD, most of the research has investigated the effects of exercise only on motor symptoms. Few previous studies have analyzed the effects of exercise on cognitive functions and the findings are controversial. Reuter et al. (1999) found no improvement on cognitive functions of the PD patients after a short period of exercise (6-weeks), while Cruise et al. (2011) and Tanaka et al. (2009) found a beneficial contribution for exercise (12 weeks and 6 months, respectively) training on executive functioning of PD patients. Therefore, different exercise programs can distinctively improve the psychological and cognitive symptoms of PD patients. In this context, the current study assessed the effects of two different 4-month exercise programs on psychological and cognitive functions in PD patients. We expected that the exercise programs would be effective in improving cognitive and psychological function of patients with PD.

\section{Method}

\section{Participants}

Forty-five patients (Table 1) with PD volunteered to participate in the study. All had a diagnosis of idiopathic PD, with no other major neurological problems. Diagnosis of PD was made using the United Kingdom Parkinson's Disease Society Brain Bank clinical criteria for idiopathic PD (Hughes, Daniel, Kilford, \& Lees, 1992). This study follows the guidelines of the Declaration of Helsinki, and it was approved by the local ethics committee (\#1058).

Inclusion criteria were disease at Stages 1-3 on the Hoehn and Yahr Rating Scale (H\&Y) (Goetz, Poewe, Rascol, Sampaio, Stebbins, Counsell et al., 2004; Hoehn \& Yahr, 1967), independent walker, and no cognitive impairment, as judged by the Mini-Mental Status Exam (MMSE) (Folstein, Folstein, \& Mchugh, 1975). Brucki et al.'s (Brucki, Nitrini, Caramelli, Bertolucci, \& Okamoto, 2003) suggestions for using the MMSE in Brazil (cutoff score according to educational level) were followed to screen for cognitive impairment. Exclusion criteria were any history of orthopedic, cardiovascular, or psychiatric disorders, as judged by the clinical assessment. No participant suffered from freezing of gait. The participants were randomized in three intervention programs: Group 1 (G1; $\mathrm{n}=15)$, Group $2(\mathrm{G} 2 ; \mathrm{n}=15)$ and Group $3(\mathrm{G} 3 ; \mathrm{n}=15)$. Figure 1 shows the flow diagram for the 34 individuals who completed the study. Individuals participated in a 4-month, exercise program described under the training protocol section. Levodopa intake remained unchanged for all participants during the intervention.

\section{Training protocol}

The purposes of each intervention program were: a) G1 to promote psychosocial interaction through non-motor activities, mainly cognitive domains, focusing on different 
Table 1. Characteristics of the groups at baseline (pretest) and after four months of participation in each of the intervention protocols (posttest). Means (standard deviation).

\begin{tabular}{|c|c|c|c|c|c|c|c|}
\hline \multirow{2}{*}{\multicolumn{2}{|c|}{ Groups }} & \multicolumn{3}{|c|}{ Pretest } & \multicolumn{3}{|c|}{ Posttest } \\
\hline & & G1 & G2 & G3 & G1 & G2 & G3 \\
\hline \multirow{3}{*}{ Participants } & Total $(n)$ & 13 & 11 & 10 & 13 & 11 & 10 \\
\hline & Male (n) & 6 & 6 & 4 & 6 & 6 & 4 \\
\hline & Female (n) & 7 & 5 & 6 & 7 & 5 & 6 \\
\hline \multicolumn{2}{|c|}{ Age (years) } & $67.31(9.03)$ & $68.45(10.81)$ & $67.5(8.26)$ & $67.31(9.03)$ & $68.45(10.81)$ & $67.5(8.26)$ \\
\hline \multicolumn{2}{|c|}{ H\&Y (Stage) } & $1.58(0.57)$ & $1.64(0.64)$ & $1.60(0.61)$ & $1.69(0.52)$ & $1.70(0.63)$ & $1.50(0.62)$ \\
\hline \multicolumn{2}{|c|}{ Disease duration time (years)* } & $6.77(4.13)$ & $4.3(2.45)$ & $6.18(6.48)$ & $6.77(4.13)$ & $4.3(2.45)$ & $6.18(6.48)$ \\
\hline \multicolumn{2}{|c|}{ UPDRS I (Score) } & $2.92(1.890$ & $3.55(2.70)$ & $2.80(1.75)$ & $2.69(1.32)$ & $3.20(2.30)$ & $3.40(1.17)$ \\
\hline \multicolumn{2}{|c|}{ UPDRS II (Score) } & $11.69(2.46)$ & $13.27(6.20)$ & $11.70(5.70)$ & $12.00(3.03)$ & $11.40(8.28)$ & $12.10(6.12)$ \\
\hline \multicolumn{2}{|c|}{ UPDRS III (Score } & $22.31(6.69)$ & $24.09(13.22)$ & $19.80(9.04)$ & $22.31(6.26)$ & $23.00(14.13)$ & $18.40(9.99)$ \\
\hline \multicolumn{2}{|c|}{ UPDRS TOTAL (Score) } & $36.92(8.65)$ & $40.91(19.58)$ & $34.30(14.24)$ & $37.00(8.49)$ & $37.60(23.92)$ & $33.9(16.37)$ \\
\hline \multicolumn{2}{|c|}{ MMSE (Score) } & $27.23(2.74)$ & $27.18(2.75)$ & $27.70(2.21)$ & $28.00(2.65)$ & $27.20(3.36)$ & $27.8(1.62)$ \\
\hline
\end{tabular}

NOTE: Group 1 (G1); Group 2 (G2); Group 3 (G3). Hoehn and Yahr Rating Scale (H\&Y). Unified Parkinson's Disease Rating Scale (UPDRS Subsections: I - Mentation, Behavior, and Mood, II - Activities of Daily Living, III - Motor examination and Total UPDRS score). MiniMental Status Examination (MMSE). *Information obtained from patient history on database.

dimensions of leisure such as crafts, artistic and intellectual competencies. This group is a control group for G2 and G3; b) G2 - multimodal exercise to develop functional capacities such as muscular resistance (specific exercises for gastrocenemius, quadriceps femoralis, hamstrings, rectus abdominalis, and trunk dorsal muscles), motor coordination (rhythmic activities), and balance (recreational motor activities); c) G3 - multimodal exercise, following the same protocol as G2, but in addition, working on balance (recreational motor activities) with emphasis on exercises for posture and gait such as educative and re-educative exercises; breathing exercises, exercises with a Bobath ${ }^{\mathrm{TM}}$ ball (low, medium and high complexity); with and without sensory manipulation (visual, vestibular and somatossensory); static and dynamic balance with and without materials usage; changes in gait velocity, direction and range of motion; regular and irregular terrains with and without obstacles and cues (visual and rhythmic). These components were selected because they seem to be affected by PD and could represent underlying mechanisms for gait and postural impairments.

The intervention programs took place over a 4-month period (60 minute sessions, twice per week). The programs were divided into three phases; each phase was composed of four cycles, totaling 32 sessions. At the end of each phase there was a progressive increase of load and task complexity. Group members who performed physical activity (G2 and G3) had their blood pressure taken during every session. Also in each session, three different participants utilized a heart rate monitor (Polar) to assess the intensity of the session. Heart rate during the main exercise sessions remained between $60 \%$ and $80 \%$ of maximum heart rate $(220$ minus the participant's age in years). Each participant was required to participate in at least $70 \%$ of the sessions in order to be included in the data analysis. No participant was absent from the intervention program for more than five consecutive sessions. The intervention programs were supervised by at least three physical education professionals at each session. No adverse events with the intervention were perceived or reported.

\section{Evaluation}

The rater was blinded as to the study's purpose and to the groups in which the patients participated. Participants were tested before beginning the intervention program (pretest) and upon completion (post-test). All assessments were carried out in the "on-medication" state (1 hour after of the medication). A neuropsychiatrist performed a clinical assessment in order to test participants on the Unified Parkinson's Disease Rating Scale (UPDRS) (Fahn \& Elton, 1987), MMSE (Brucki, Nitrini, Caramelli, Bertolucci, \& Okamoto, 2003), and Hoehn and Yahr Rating Scale (Goetz et al., 2004). For data analysis, scores on the UPDRS subsections I (metallization, behavior, and mood), II (activities of daily living), III (motor examination) and the total UPDRS score were considered separately.

Moreover, cognitive function was evaluated by the same 


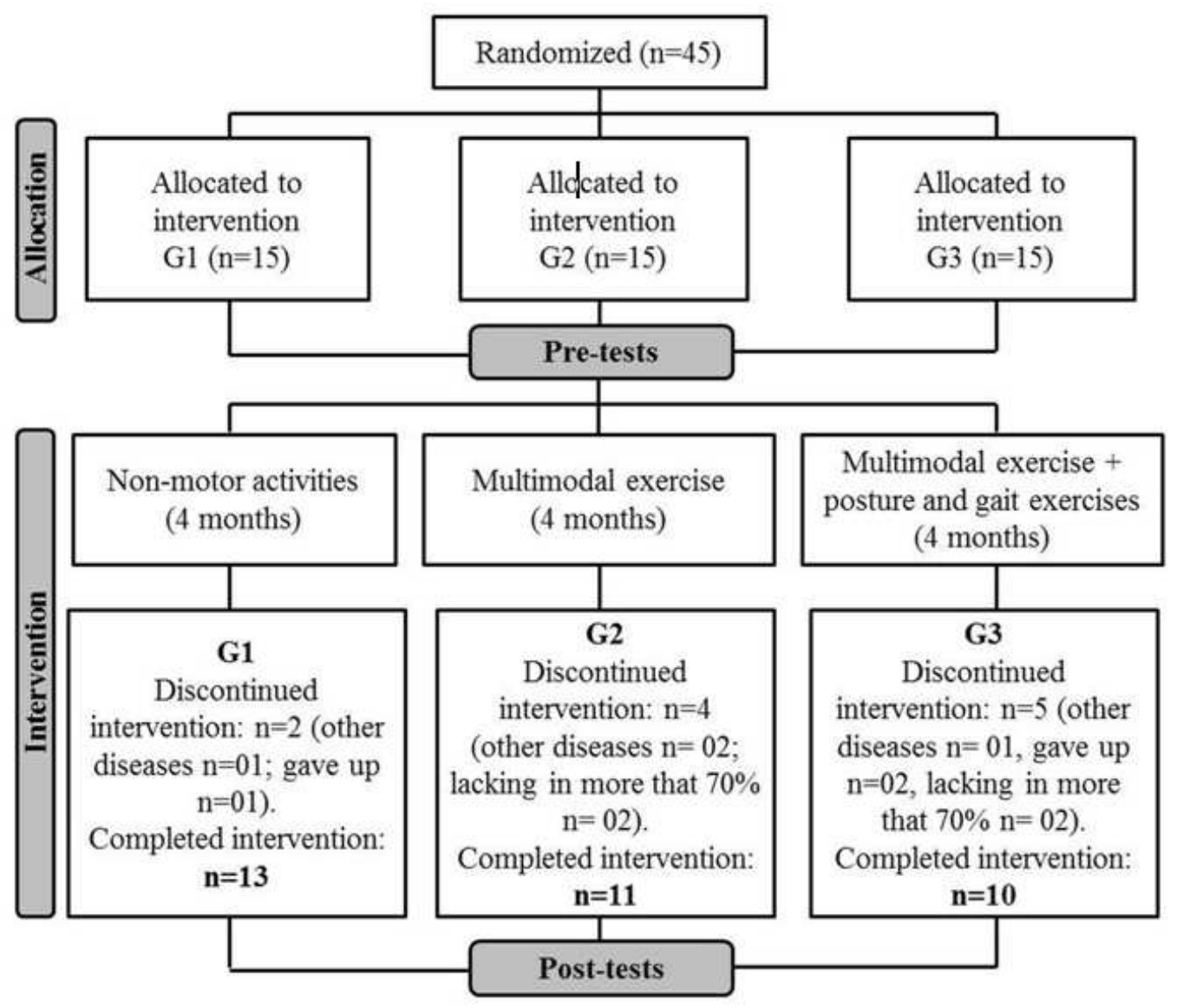

Figure 1. Flow diagram for the 34 individuals who completed the study.

trained assessor, under the same conditions, by applying the following tests: (i) Wechsler Memory Scale - Revised (WMS-R) (Wechsler, 1997) with two subtests: logical memory I and II (immediate memory, episodic declarative memory and recall ability) and verbal paired associates (easy combination I, II, III and recall late immediately, and difficult combination I, II, III and recall late after $30 \mathrm{~min}$, that analyzed immediate memory, learning, episodic declarative memory and recall ability); (ii) Lipp's Stress Symptoms Inventory (LSSI) (LIPP, 2000) for symptoms of stress-physical, psychological and overall, according to the phase in which it is found: alert, resistance and exhaustion; and (iii) Wisconsin Card Sorting Test (WCST) (Nelson, 1976) with "categories completed," "perseverative errors" and " "failure to maintain set" to analyze the executive function specifically for abstractions, mental flexibility and attention, respectively.

\section{Statistical analysis}

Statistical data analyses were performed using SPSS 10.0 software, with descriptive statistics (mean and standard deviation). One-way ANOVAs were employed for between group comparisons at the baseline. Two-way ANOVAs including group (G1, G2 and G3) and time (pre and post) were used as factors. Repeated measurements on the second factor were applied. A significance level of 0.05 was used in all statistical analyses.

\section{Results}

Only the data from participants whose attendance rate was higher than $70 \%$ were included in the analysis. The three groups were not significantly different in demographic, clinical and cognitive data at baseline (Table 1). Univariate analyses reveal significant interactions between groups and time, but the post hoc tests did not confirm the interactions. Univariate analyses for time revealed differences for LSSI physical stress II and LSSI - overall stress II, and WMS - R difficult III. Participants showed lesser LSSI - physical stress II and LSSI - overall stress II scores (Table 2) and greater WMS - R difficult III score (Table 3) at post-test than at pretest. These changes represent improvement at post-test when compared with pre-test.

\section{Discussion}

The current study assessed the effects of four months of different exercises programs on the psychological and 
Table 2. Means (standard deviation) of stress dependent variables for each group at before (pre) and after (post) intervention and statistical values. Stress I (alert phase), stress II (resistance state phase) and stress III (exhaustion state phase).

\begin{tabular}{|c|c|c|c|c|c|c|}
\hline \multirow[b]{2}{*}{ Measure } & & \multicolumn{3}{|c|}{ Group } & \multirow[b]{2}{*}{ Interaction } & \multirow[b]{2}{*}{ Main effect of time } \\
\hline & & $\begin{array}{c}\text { Functional } \\
\text { Capacity }\end{array}$ & Mobility & Control & & \\
\hline \multirow{2}{*}{ LSSI - physical stress I } & Pre & $2.23(1.83)$ & $3(1.05)$ & $3.18(1.54)$ & \multirow{2}{*}{$\mathrm{F}_{2,31}=0.054, \mathrm{P}<0.95$} & \multirow{2}{*}{$\mathrm{F}_{1,31}=0.3, \mathrm{P}<0.59$} \\
\hline & Post & $2.08(2.43)$ & $2.6(1.71)$ & $3.09(2.25)$ & & \\
\hline \multirow{2}{*}{ LSSI - psychological stress I } & Pre & $0.61(0.97)$ & $0.7(0.82)$ & $0.9(1.04)$ & \multirow{2}{*}{$\mathrm{F}_{2,31}=0.098, \mathrm{P}<0.91$} & \multirow{2}{*}{$\mathrm{F}_{1,31}=0.81, \mathrm{P}<0.37$} \\
\hline & Post & $0.69(0.63)$ & $1(1.05)$ & $1.09(1.04)$ & & \\
\hline \multirow{2}{*}{ LSSI - overall stress I } & Pre & $2.85(2.64)$ & $3.7(0.67)$ & $4.1(1.97)$ & \multirow{2}{*}{$\mathrm{F}_{2,31}=0.017, \mathrm{P}<0.98$} & \multirow{2}{*}{$\mathrm{F}_{1,31}=0.003, \mathrm{P}<0.95$} \\
\hline & Post & $2.77(2.52)$ & $3.6(2.17)$ & $4.18(2.18)$ & & \\
\hline \multirow{2}{*}{ LSSI - physical stress II } & Pre & $2.54(2.22)$ & $4.1(1.66)$ & $3.18(1.33)$ & \multirow{2}{*}{$\mathrm{F}_{2,31}=0.89, \mathrm{P}<0.42$} & \multirow{2}{*}{$F_{1,31}=6.87, P<0.01$} \\
\hline & Post & $2(2.3)$ & $2.6(2.11)$ & $2.64(2.06)$ & & \\
\hline \multirow{2}{*}{ LSSI - psychological stress II } & Pre & $1.31(1.8)$ & $1.8(1.13)$ & $1.73(1)$ & \multirow{2}{*}{$\mathrm{F}_{2,31}=0.73, \mathrm{P}<0.49$} & \multirow{2}{*}{$\mathrm{F}_{1,31}=0.65, \mathrm{P}<0.42$} \\
\hline & Post & $0.92(1.44)$ & $1.5(1.08)$ & $1.91(1.3)$ & & \\
\hline \multirow{2}{*}{ LSSI - overall stress II } & Pre & $3.84(3.87)$ & $5.9(2.42)$ & $4.91(1.51)$ & \multirow{2}{*}{$\mathrm{F}_{2,31}=0.71, \mathrm{P}<0.5$} & \multirow{2}{*}{$F_{1,31}=4.61, P<0.04$} \\
\hline & Post & $2.92(3.52)$ & $4.1(2.6)$ & $4.54(2.94)$ & & \\
\hline \multirow{2}{*}{ LSSI - physical stress III } & Pre & $1.92(1.7)$ & $2.6(1.77)$ & $2.27(2)$ & \multirow{2}{*}{$\mathrm{F}_{2,31}=0.14, \mathrm{P}<0.87$} & \multirow{2}{*}{$\mathrm{F}_{1,31}=2.28, \mathrm{P}<0.141$} \\
\hline & Post & $1.46(1.56)$ & $2.2(2.04)$ & $2.09(1.81)$ & & \\
\hline \multirow{2}{*}{ LSSI - psychological stress III } & Pre & $3(3.63)$ & $4.4(2.41)$ & $3.64(2.5)$ & \multirow{2}{*}{$\mathrm{F}_{2,31}=1.11, \mathrm{P}<0.34$} & \multirow{2}{*}{$\mathrm{F}_{1,31}=1.65, \mathrm{P}<0.21$} \\
\hline & Post & $2.85(2.99)$ & $3.1(2.02)$ & $3.64(2.65)$ & & \\
\hline \multirow{2}{*}{ LSSI - overall stress III } & Pre & $4.92(5.04)$ & $7(3.23)$ & $5.91(2.81)$ & \multirow{2}{*}{$\mathrm{F}_{2,31}=0.95, \mathrm{P}<0.39$} & \multirow{2}{*}{$\mathrm{F}_{1,31}=3.49, \mathrm{P}<0.071$} \\
\hline & Post & $4.31(4.25)$ & $5.3(3.68)$ & $5.72(3.1)$ & & \\
\hline
\end{tabular}

Table 3. Means (standard deviation) of memory and executive functions (EF) dependent variables for each group at before (pre) and after (post) intervention and statistical values. Verbal Paired Associates (WMS - easy I, II, III and late and difficult I, II, III and late) analyzed immediate memory, learning, episodic declarative memory and the ability to recall. Logical memory I and II analyzed immediate memory, episodic declarative memory and the ability to recall. Perseverative errors, categories completed and failure to maintain set analyzed abstraction, mental flexibility and attention respectively.

\begin{tabular}{|c|c|c|c|c|c|c|}
\hline \multirow[b]{2}{*}{ Measure } & & \multicolumn{3}{|c|}{ Group } & \multirow[b]{2}{*}{ Interaction } & \multirow[b]{2}{*}{ Main effect of time } \\
\hline & & $\begin{array}{c}\text { Functional } \\
\text { Capacity }\end{array}$ & Mobility & Control & & \\
\hline WMS - easy I & Pre & $3.46(0.77)$ & $2.9(0.87)$ & $3.09(0.83)$ & $\mathrm{F}_{2,31}=2.09, \mathrm{P}<0.14$ & $F_{1,31}=0.009, P<0.92$ \\
\hline & Post & $3.15(1.07)$ & $2.9(1.1)$ & $3.36(0.67)$ & & \\
\hline WMS - easy II & $\begin{array}{l}\text { Pre } \\
\text { Post }\end{array}$ & $\begin{array}{l}3.77(0.6) \\
3.77(0.6)\end{array}$ & $\begin{array}{l}3.3(0.82) \\
3.6(0.7)\end{array}$ & $\begin{array}{l}3.54(0.69) \\
3.27(0.64)\end{array}$ & $\mathrm{F}_{2,31}=1.86, \mathrm{P}<0.17$ & $\mathrm{~F}_{1,31}=0.006, \mathrm{P}<0.94$ \\
\hline WMS - easy III & $\begin{array}{l}\text { Pre } \\
\text { Post }\end{array}$ & $\begin{array}{c}3.76(0.6) \\
3.46(1.13)\end{array}$ & $\begin{array}{l}3.4(0.7) \\
3.7(0.48)\end{array}$ & $\begin{array}{c}3.72(0.47) \\
3.64(0.5)\end{array}$ & $F_{2,31}=3.33, P<0.05$ & $\mathrm{~F}_{1,31}=0.11, \mathrm{P}<0.74$ \\
\hline WMS - easy late & $\begin{array}{l}\text { Pre } \\
\text { Post }\end{array}$ & $\begin{array}{c}3.77(0.6) \\
3.61(0.87)\end{array}$ & $\begin{array}{l}3.3(0.67) \\
3.3(1.34)\end{array}$ & $\begin{array}{c}3.81(0.4) \\
3.91(0.92)\end{array}$ & $\mathrm{F}_{2,31}=0.31, \mathrm{P}<0.74$ & $\mathrm{~F}_{1,31}=0.02, \mathrm{P}<0.88$ \\
\hline WMS - difficult I & $\begin{array}{l}\text { Pre } \\
\text { Post }\end{array}$ & $\begin{array}{l}0.92(0.86) \\
1.46(1.33)\end{array}$ & $\begin{array}{l}0.6(0.96) \\
0.6(0.97)\end{array}$ & $\begin{array}{c}0.72(1) \\
1.18(1.17)\end{array}$ & $\mathrm{F}_{2,31}=0.82, \mathrm{P}<0.45$ & $\mathrm{~F}_{1,31}=3.36, \mathrm{P}<0.08$ \\
\hline WMS - difficult II & $\begin{array}{l}\text { Pre } \\
\text { Post }\end{array}$ & $\begin{array}{l}1.31(1.11) \\
1.85(1.62)\end{array}$ & $\begin{array}{l}1.9(1.2) \\
1(0.94)\end{array}$ & $\begin{array}{l}1.18(0.98) \\
1.27(1.27)\end{array}$ & $\mathrm{F}_{2,31}=2.93, \mathrm{P}<0.07$ & $\mathrm{~F}_{1,31}=0.13, \mathrm{P}<0.72$ \\
\hline WMS - difficult III & $\begin{array}{l}\text { Pre } \\
\text { Post }\end{array}$ & $\begin{array}{l}1.85(0.99) \\
2.54(1.2)\end{array}$ & $\begin{array}{l}1.6(0.84) \\
2.1(1.1)\end{array}$ & $\begin{array}{l}1.45(1.21) \\
2.1(1.3)\end{array}$ & $F_{2,31}=0.15, P<0.86$ & $F_{1,31}=17.74, P<0.001$ \\
\hline WMS - difficult late & $\begin{array}{l}\text { Pre } \\
\text { Post }\end{array}$ & $\begin{array}{l}1.38(1.19) \\
1.7(1.11)\end{array}$ & $\begin{array}{l}1.5(1.27) \\
1.4(1.07)\end{array}$ & $\begin{array}{l}1.45(1.21) \\
1.54(1.44)\end{array}$ & $\mathrm{F}_{2,31}=0.79, \mathrm{P}<0.46$ & $\mathrm{~F}_{1,31}=0.55, \mathrm{P}<0.46$ \\
\hline Memory I & $\begin{array}{l}\text { Pre } \\
\text { Post }\end{array}$ & $\begin{array}{c}23.31(8.57) \\
24(8.18)\end{array}$ & $\begin{array}{l}22.7(7.99) \\
20.3(7.47)\end{array}$ & $\begin{array}{l}15.18(8.97) \\
20.27(8.23)\end{array}$ & $\mathrm{F}(2.31)=5.7 \quad \mathrm{P}<0.007$ & $\mathrm{~F}_{1,31}=1.62, \mathrm{P}<0.21$ \\
\hline Memory II & $\begin{array}{l}\text { Pre } \\
\text { Post }\end{array}$ & $\begin{array}{l}19.15(9.02) \\
19.7(9.64)\end{array}$ & $\begin{array}{l}17.2(9.14) \\
18.3(10.57)\end{array}$ & $\begin{array}{l}14.27(9.04) \\
17.72(7.86)\end{array}$ & $\mathrm{F}_{2,31}=1.02, \mathrm{P}<0.37$ & $F_{1,31}=3.6, P<0.07$ \\
\hline EF - perseverative errors & $\begin{array}{l}\text { Pre } \\
\text { Post }\end{array}$ & $\begin{array}{l}12.08(7.13) \\
10.38(6.6)\end{array}$ & $\begin{array}{c}13.5(5.06) \\
11.6(6.7)\end{array}$ & $\begin{array}{l}10.54(6.73) \\
11.36(8.08)\end{array}$ & $\mathrm{F}_{2,31}=0.99, \mathrm{P}<0.38$ & $\mathrm{~F}_{1,31}=1.12, \mathrm{P}<0.29$ \\
\hline EF - categories completed & $\begin{array}{l}\text { Pre } \\
\text { Post }\end{array}$ & $\begin{array}{l}2.54(1.26) \\
2.77(1.23)\end{array}$ & $\begin{array}{c}2.5(0.7) \\
2.7(0.67)\end{array}$ & $\begin{array}{l}1.81(1.94) \\
1.82(1.83)\end{array}$ & $\mathrm{F}_{2,31}=0.25, \mathrm{P}<0.78$ & $\mathrm{~F}_{1,31}=0.98, \mathrm{P}<0.32$ \\
\hline $\mathrm{EF}$ - failure to maintain set & $\begin{array}{l}\text { Pre } \\
\text { Post }\end{array}$ & $\begin{array}{c}1.61(1.76) \\
1(0.82)\end{array}$ & $\begin{array}{l}0.4(0.51) \\
0.1(0.32)\end{array}$ & $\begin{array}{l}1.27(1.83) \\
1.82(1.33)\end{array}$ & $\mathrm{F}_{2,31}=2.03, \mathrm{P}<0.15$ & $\mathrm{~F}_{1,31}=0.25, \mathrm{P}<0.62$ \\
\hline
\end{tabular}


cognitive functions of PD patients. The main results of this study indicate that four months of motor exercise were similarly efficient for cognitive activities, executive functions and the psychological condition of patients with PD. Therefore, the involvement of participants in group activities, regardless of the type of activity, was effective in reducing physical stress and improving episodic declarative memory, evaluated by the verbal paired associates (difficult combination, after the learning period of the test).

Four months or less of exercise intervention has been effective in improving the motor symptoms of PD patients (Protas, Mitchell, Williams, Qureshy, Caroline, \& Lai, 2005; Ridgel, Vitek, \& Alberts, 2009; Sage \& Almeida 2010). The two physical exercise programs were equal in efficiency to the cognitive training (control group). Furthermore, both exercise programs were as efficient as the program without physical exercise in improving the psychological and cognitive functions of these patients. Thus, the observed improvements in relation to memory and stress could be attributed to social interaction promoted by group work, since the group that didn't participate in exercise programs also showed improvement in these functions.

The improvement in stress symptoms observed after participation in group activities is an important outcome for people with PD. Although the pathology and symptoms of PD have been widely investigated, the factors involved in onset and course of this disease are not understood. However, some physiological conditions, such as stress, could be related to the diversity of symptoms during the course of disease progression and among the patients population, as well as to the individual response to medication after the onset of PD (Foley, Gerlach, Double, \& Riederer, 2004). Furthermore it has been suggested that acute or chronic stress might lead to earlier onset or worsening of the motor symptoms of PD (Smith, Castro, \& Zigmond, 2002; Treves, Rabey \& Korczyn, 1990). The high density of glucocorticoid receptors in some brain areas linked to the motor control, such as the cerebellum, basal ganglia and motor cortex, render these areas susceptible to the effects of stress (Ahima \& Harlan, 1990; Ahima, Tagoe, \& Harlan, 1991). In addition, it has been demonstrated that oxidative stress caused by immobilization stress selectively damages the nigrostriatal dopaminergic system (Kim, Choi, Chang, Kim, \& Hwang, 2005), indicating that the dopaminergic system is particularly susceptible to the effects of stress (Izzo, Sanna, \& Koob, 2005; Pani, Porcella, \& Gessa, 2000). Thus, although stress-related studies of PD are restricted, some evidence has been suggested that stress and stress hormones represent a critical cofactor in this pathology. Thus, we can speculate that the improvement in symptoms of stress observed in our study could lead to reduced motor symptoms and improve the functionality of the patients in the long term.

The decrease in stress symptoms also could explain the improvement in episodic declarative memory performance. Unlike brief periods of stress, which are rather thought to enhance cognition (Lupien, Maheu, Tu, Fiocco, \& Schramek,
2007), more severe or prolonged stressors can have deleterious effects on cognitive performance (Jameison \& Dinan, 2001). Permanently increased circulating glucocorticoid levels have been shown to be associated with reduced hippocampal volume and consequently with some memory impairment (Jameison \& Dinan, 2001; Sterlemann, Rammes, Wolf, Liebl, Ganea, Müller et al., 2010). However, different domains of memory systems depend on different anatomical structures. The short-term memory is located in the hippocampus and adjacent cortical areas of the temporal lobe. On the other hand, episodic declarative memory is spread onto the medial temporal lobe, anterior thalamic nucleus, mammillary bodies, fornix, and prefrontal cortex (Robertson, 2002; Budson \& Price, 2005). Accordingly, although studies of stress and memory have not reported physiological changes in these regions, specifically for episodic declarative memory, these regions are linked to other cognitive functions, such as executive functions accessed by the prefrontal cortex, which are directly influenced by stress and its hormonal changes. These findings reinforce the hypothesis that an improvement in stress may have influenced performance on episodic declarative memory of the patients.

The improvement in memory performance also can be a direct response to involvement in the proposed activities. In our study, each group of patients participated in different programs of activities. Two groups participated in the exercise programs and a third group participated in the nonmotor activities that involved some cognitive tasks. Thus, the absence of group interaction and the main effect of time observed in the improvement of episodic declarative memory may indicate that both physical exercise and cognitive activities with tasks that require memory components are effective in improving specific memory areas.

Unlike our study, Tanaka et al. (2009) found significant improvement in executive functions of PD patients after participating in a physical activity program. In our study, we had an exercise program similar to Tanaka et al. (2009) and another program that added specific posture and gait training and there was no difference between the groups who performed physical activities and those who did non-motor activities. However, our study was developed for four months, twice a week, while Tanaka's study was developed for 6 months, three times a week. On the other hand, Cruise et al. (2011) conducted an aerobic program for 12 weeks (twice per week) and they observed improvements in frontal lobe based executive functions, but neither in mood nor in disease-related quality of life. Therefore, we can infer that exercise type, frequency and duration can differently affect the psychological and cognitive functions of PD patients.

In conclusion we can state that motor and non-motor programs improve similarly the cognitive functions and psychological conditions of patients with PD. In addition, group activities may be recommended to reduce the symptoms of stress and improve declarative episodic memory in PD patients, regardless of whether such activities are motor or non-motor. 
Although the findings shed some light on the effects of exercise programs on the psychological and cognitive functions in people with PD, some limitations are evident. Future research should include a control group with PD individuals without any type of exercise, which could elucidate the effects of exercise on the psychological and cognitive domains. Moreover, including groups of individuals without neurodegenerative disease could also help to improve knowledge about the effects of exercise.

\section{References}

Aarsland, D., Andersen, K., Larsen, J. P., Lolk, A., \& KraghSorensen, P. (2003). Prevalence and characteristics of dementia in Parkinson disease. An 8- year prospective study. Archives of Neurology, 60, 387-392.

Aarsland, D., Bronnick, K., Williams-Gray, C., Weintraub, D., Marder, K., Kulisevsky, J., ... Emre, M. (2010). Mild cognitive impairment in Parkinson disease: a multicenter pooled analysis. Neurology, 75, 1062-1069.

Ahima, R. S., Tagoe, C. N. B., \& Harlan, R. E. (1991). Type II corticosteroid receptor-like immunoreactivity in the rat cerebellar cortex: differential regulation by corticosterone. Neuroendocrinology, 55, 683-694.

Ahima, R. S., \& Harlan, R. E. (1990). Charting of Type II glucocorticoid receptor-like immunoreactivity in the rat central nervous system. Neuroscience, 39, 579-604.

Barbosa, M. T., Caramelli, P., Maia, D. P., Cunningham, M. C. Q., Guerra, H. L., Lima-Costa, M. F. \& Cardoso, F. (2006). Parkinsonism and Parkinson's disease in the elderly: a community-based survey in Brazil (the Bambuí Study). Movement Disorders, 21(6), 800-808.

Braak, H., Rub, U., \& Del Tredici, K. (2006). Cognitive decline correlates with neuropathological stage in Parkinson's disease. Journal of Neurological Sciences, 248(1-2), 255-258.

Bronnick, K., Ehrt, U., Emre, M., De Deyn, P. P., Wesnes, K., Tekin, S., \& Aarsland, D. (2006). Attentional deficits affect activities of daily living in dementia associated with Parkinson's disease. Journal of Neurology, Neurosurgery and Psychiatry, 77(10), 1136-1142.

Brucki, S. M. D., Nitrini, R., Caramelli, P., Bertolucci, P. H. F., \& Okamoto, I. H. (2003). Suggestions for utilization of the minimental state examination in Brazil. Arquivos de NeuroPsiquiatria, 61(3B), 777-781.

Budson, A. E., \& Price, B. H. Memory dysfunction. (2005). New England Journal of Medicine, 352, 692-699.

Chodzko-Zajko, W. J., Proctor, D. N., Fiatarone-Singh, M. A., Minson, C. T., Nigg, C. R., Salem, G. J., \& Skinner, J. S. (2009). Exercise and Physical Activity for Older Adults. Medicine \& Science in Sports \& Exercise, 41(7), 1510-1530.

Cruise, K. E., Bucks, R. S., Loftus, A. M., Newton, R. U., Pegoraro, R., \&Thomas, M. G. (2011). Exercise and Parkinson's: benefits for cognition and quality of life. Acta Neurologica Scandinavica, 123, 13-19.

Devos, H., Vandenberghe, W., Nieuwboer, A., Tant, M., Baten, G., \& De Weerdt, W. (2007). Predictors of fitness to drive in people with Parkinson disease. Neurology, 69(14), 1434-1441.

Fahn, S., \& Elton, R. Members of the UPDRS. Development Comitee. (1987). The Unified Parkinson's disease rating scale. In: Fahn, S., Marsden, C. D., Calne, D. B., \& Goldstein, M. (Eds), Recent Developments in Parkinson's Disease (2, pp. 153-164). Florham Park NJ: Mcmellam Health Care
Information.

Foley, P., Gerlach, M., Double, K.L. \& Riederer, P. (2004) Dopamine receptor agonists in the therapy of Parkinson's disease. Journal of Neural Transmission, 111, 1375-1446.

Folstein, M. F., Folstein, S. E., \& Mchug, P. R. (1975). Minimental state: a practical method for grading the cognitive state of patients for the clinician. Journal of Psychiatry Research, 12, 189-198.

Goetz, C. G., Poewe, W., Rascol, O., Sampaio, C. Stebbins, G. T., Counsell, C., ... Seidl, L. (2004). Movement Disorder Society Task Force report on the Hoehn and Yahr staging scale: status and recommendations. Movement Disorders, 19, 1020-1028.

Hely, M. A., Morris, J.G.L., Reid, W.G.J., Adena, M.A., \& Halliday, G.M. (2008). Sydney Multicenter Study of Parkinson's disease: the inevitability of dementia at 20 years. Movement Disorders, 23, 837-844.

Hirsch, M. A., Toole, T., Maitland, C. G., \& Rider, R. A. (2003). The effects of balance training and high-intensity resistance training on persons with idiopathic Parkinson's disease. Archives of Physical Medicine and Rehabilitation, 84, 11091117.

Hoehn, M. M., \& Yahr, M. D. (1967). Parkinsonism: onset, progression and mortality. Neurology, 17, 573-581.

Hughes, A.J., Daniel, S.E., Kilford, L., \& Lees, A.J. (1992). Accuracy of clinical diagnosis of idiopathic Parkinson's disease: a clinico-pathological study of 100 cases. Journal of Neurology, Neurosurgery and Psychiatry, 55, 181-84.

Izzo, E., Sanna, P.P., \& Koob, G.F. (2005). Impairment of dopaminergic system function after chronic treatment with corticotropin-releasing factor. Pharmacology, Biochemistry and Behavior, 81, 701-708.

Jameison, K., \& Dinan, T.G. (2001). Glucocorticoids and cognition: From physiology to pathophysiology. Human Psychopharmacology: Clinical and Experimental, 16, 293-302.

Karlsen, K. H., Tandberg, E., Arsland, E., D., \& Larsen, J. P. (2000). Health related quality of life in Parkinson's disease: a prospective longitudinal study. Journal of Neurology Neurosurgery and Psychiatry, 69(5), 584-589.

Kim, S.T., Choi, J.H., Chang, J.W., Kim, S.W. \& Hwang, O. (2005). Immobilization stress causes increases in tetrahydrobiopterin, dopamine, and neuromelanin and oxidative damage in the nigrostriatal system. Journal of Neurochemistry, 95, 89-98.

Korczyn, A.D. (2001). Dementia in Parkinson's disease. Journal of Neurology, 248(suppl 3), III/1-III/4.

Lipp, M. E. M. (2000). Manual do Inventário de Sintomas de Stress para adultos de Lipp (ISSL). São Paulo: Casa do psicólogo.

Lupien, S.J., Maheu, F., Tu, M., Fiocco, A., \& Schramek, T.E. (2007). The Effects of Stress and Stress Hormones on Human Cognition: Implications for the Field of Brain and Cognition. Brain \& Cognition, 65(3), 209-237.

Nelson, H. E. (1976). A modified card sorting test sensitive to frontal lobe defects. Cortex, 12, 313-324.

Olanow, C. W., Stern, M. B., \& Sethi, K. (2009). The scientific and clinical basis for the treatment of Parkinson disease. Neurology, 72, Suppl. 4, S1-S136.

Pani, L., Porcella, A., \& Gessa, G.L. (2000). The role of stress in the pathophysiology of the dopaminergic system. Molecular Psychiatry, 5, 14-21.

Parashos, S. A., Maraganore, D. M., O'brien, P. C., \& Rocca, W. A. (2002). Medical Services Utilization and Prognosis in Parkinson Disease: A Population-Based Study. Mayo Clinic Proceedings, 77, 918-925.

Pereira, M. P., Ferreira, M. D. T. O., Caetano, M. J. D. C., Vitório, 
R., Lirani-Silva, E., Barbieri, F. A., ... Gobbi, L. T. B. (2012), Long-Term Multimodal Exercise Program Enhances Mobility of Patients with Parkinson's Disease. ISRN Rehabilitation. doi:10.5402/2012/491718. Retrieved from http://www.hindawi. com/isrn/rehabilitation/2012/491718/.

Protas, E.J., Mitchell, K., Williams, A., Qureshy, H., Caroline, K., \& Lai, E.C. (2005). Gait and step training to reduce falls in Parkinson's disease. NeuroRehabilitation, 20, 183-90.

Reuter, I., Engelhardt, M., Stecker, K., \& Baas, H. (1999). Therapeutic value of exercise training in Parkinson's disease. Medicine and Science in Sports and Exercise, 31(11), 15441549.

Ridgel, A., Vitek, J., \& Alberts, J. (2009). Forced, not voluntary, exercise improves motor function in Parkinson's disease patients. Neurorehabilitation and Neural Repair, 23, 600-608.

Robertson, L. (2002). Memory and the brain. Journal of Dental Education, 66(1), 30-42.

Sage, M., \& Almeida, Q. (2010). A positive influence of vision on motor symptoms during sensory attention focused exercise for Parkinson's disease. Movement Disorders, 25, 64-69.

Sage, M.D., \& Almeida, Q.J. (2009). Symptom and gait changes after sensory attention focused exercise vs aerobic training in Parkinson's disease. Movement disorders: Movement Disorder, 24(8), 1132-8

Sawamoto, N., Piccini, P., Hotton, G., Pavese, N., Thielemans, K., \& Brooks, D.J. (2008). Cognitive defi cits and striatofrontal dopamine release in Parkinson's disease. Brain, 131, 1294-1302.

Smith, A.D., Castro, S.L. \& Zigmond, M.J. (2002) Stress-induced Parkinson's disease: a working hypothesis. Physiology and Behavior, 77, 527-531.

Sterlemann, V., Rammes, G., Wolf, M., Liebl, C., Ganea, K., Müller, M.B., \& Schmidt, M.V. (2010). Chronic social stress during adolescence induces cognitive impairment in aged mice. Hippocampu, 20, 540-549.

Tanaka, K. Quadros Júnior, A. C., Santos, R. F., Stella, F., Gobbi, L. T., \& Gobbi, S. (2009). Benefits of physical exercise on executive functions in older people with Parkinson's disease. Brain and Cognition, 69(2),435- 41.

Treves, T.A., Rabey, J.M., \& Korczyn, A.D. (1990). Case-control study, with use of temporal approach, for evaluation of risk factors for Parkinson's disease. Movement Disorder, 5 (Suppl. $1), 11$.

Van Nimwegen, M., Speelman, A. D., Overeem, S., van de Warrenburg, B. P., Smulders, K., Dontje, M. L., ... Munneke, M. (2013). Promotion of physical activity and fitness in sedentary patients with Parkinson's disease: randomized controlled trial. BMJ 2013, 346, f576.

Vitório, R., Teixeira-Arroyo, C., Lirani-Silva, E., Barbieri, F. A., Caetano, M. J. D., Gobbi, S., Stella, F., \& Gobbi, L. T. B. (2011). Effects of 6-Month, Multimodal Exercise Program on Clinical and Gait Parameters of Patients with Idiopathic Parkinson's Disease: A Pilot Study. ISRN Neurology. Retrieved from http://downloads.isrn.com/journals/neurology/2011/ 714947.pdf.

Wechsler, D. (1997). The Wechsler Memory Scale - III Revised (Manual). Santo Antonio Texas: Psychological Corporation.

Wielinski, C.L., Erickson-Davis, C., Wichmann, R., Walde-Douglas, M., \& Parashos, S.A. (2005). Falls and injuries resulting from falls among patients with Parkinson's disease and other parkinsonian syndromes. Movement Disorder, 20(4):410-415.

\section{Authors' note}

\section{Correspondence}

Dr. Lilian T.B. Gobbi

LEPLO - Laboratório de Estudos da Postura e da Locomoção UNESP

Av. 24-A, 1515, Bela Vista, Rio Claro 13506-900 SP, Brazil

This study was presented as part of an invited lecture at the $8^{\text {th }}$ International Congress of Physical Education and Human Movement and $14^{\text {th }}$ Symposium Paulista Physical Education.

Declaration of Conflicting Interests: The authors declared no conflicts of interest with respect to the research, authorship, and/ or publication of this article.

Manuscript received on March 30, 2013

Manuscript accepted on May 10, 2013 